УДК 159. 923.2

doi: $10.15330 /$ ps.9.1.96-104

Зіновія Карпенко

Прикарпатський національний університет імені Василя Стефаника

karpenkozs@ukr.net

\title{
З ДОСВІДУ ЗАСТОСУВАННЯ АВТОБІОГРАФІЧНОГО НАРАТИВУ В ОРГАНІЗАЦІЙНІЙ ПСИХОЛОГІЇ: АКСІОЛОГІЧНА ОПТИКА
}

3 позицій постнекласичної раџіональності та пост-постмодерністських пошуків холістичного підходу до трактування психології особи як інтегрального суб'єкта життєздійснення висвітлено досвід застосування автобіографічного наративу в контексті управління $і$ розв'язання складних (часто заміщених) конфліктів у організаційному середовищі вищої школи. Стверджується, щуо такий наратив конструюється суб'єктом як автором власного життя й інсайдером у царині унікального життєвого досвіду та репрезентанта особистісно значущих прагнень $i$ иілей. Діалогічна інтенція автобіографічного наративу потребує достовірного опису суб'єктивної реальності Автора у спосіб первинного феноменологічного вчування - занурення у світ інтимних переживань і метафоричних кодів несвідомого і вторинного дискурсивного впорядкування описаних подій та їх оцінок иляхом розгляду індивідуальної історї в контексті реальних міжособистісних стосунків (інтерпретація для себе і тлумачення для Іншого власної версї̈ прожитого і пережитого).

Аргументовано аксіопсихологічні критерії валідності автобіографічного наративу як засобу ініціювання $з$ боку керівника продуктивної діалогічної комунікації задля зміцнення здорових тенденцій розвитку освітньонаукових організацій в контексті євроінтеграційних процесів, гармонізації персональних траєкторій професійнокар'єрного зростання у межах первинного колективу; посилення особистої відповідальності за результати морального самовизначення в критичних ситуаціях; формування толерантності до невизначеності та готовності до ухвалення нестандартних рішень як можливості підтримати перспективні лінії розвитку, відкинувши ригідні, застарілі практики освітнього менеджменту.

Ключові слова: автобіографічний наратив, наративна психологія, аксіологічна психологія, організаційна психологія, особа як інтегральний суб'єкт, конфлікт, вища школа.

Постановка проблеми. Постнекласичний тип наукової раціональності на історичному відтинку епохи Постмодерну позначений пошуками способів епістемологічної й методологічної тріангуляції на кшталт практикування так званих «змішаних методів», базованих на стратегії взаємного доповнення якісних досліджень кількісними, або (у вужчому сенсі) знаходження можливостей урівноваження суб'єктивних переваг i вибіркових аксіологічних акцентів «дослідника» персональною версією опису i тлумачення психологічних феноменів «досліджуваного». Застосування лапок у цьому контексті виправдане насамперед тією обставиною, що в сучасному постіндустріальному, інформаційному суспільстві його тотальна транзитивність - перманентно перехідний стан, зумовлений надзвичайною інтенсивністю технологічних i соціокультурних змін - об’єктивно генерує запит на відсепарування еволюційно перспективних тенденцій розвитку в різних царинах людського буття від застарілого й девіантного, що неможливо без релятивізації позицій суб'єкта і об'єкта, дослідника і досліджуваного, лікаря і пацієнта, вчителя і учня, керівника і підлеглого тощо.

Умовність і факультативність займаних позицій та індивідуальних статусів є відображенням швидкоплинності сучасних суспільних процесів, які потребують як від окремих осіб, так і від різних спільнот, 3-поміж інших - професійних організацій, толерантності до невизначеності, відкритості до нового досвіду, в тому числі й готовності до взаємного обернення позицій у владно-підвладних стосунках. Таким чином, раніше окреслена проблема тріангуляції, окрім наукового, набуває додаткового - аксіологічного і передовсім моральнопрагматичного змісту. В царині практичної організаційної психології це може означати застосування досвіду наративної психології та психотерапії до розв'язання іiї актуальних завдань 3 оптимізації організаційного клімату, підвищення корпоративної культури та етики ділових взаємин, досягнення кращої ефективності роботи виробничого підрозділу шляхом підтримки мотивації кар'єрного зростання його працівників і т. ін. Відтак реалізація триєдиного 
завдання епістемологічної, методологічної й наративно-аксіологічної тріангуляції в постсучасному транзитивному суспільстві набуває чималої актуальності.

Мета дослідження. У цій статті авторка здійснює спробу об'єктивації власного досвіду застосування автобіографічного наративу 3 метою оптимізації статусно-рольових, компетентнісно-ділових, ціннісно-орієнтаційних, морально-етичних, а також здоров'язберігальних (екологічних) параметрів функціонування окремого організаційного підрозділу (наприклад, кафедри) з урахуванням його субсистемних (особистісних властивостей працівників) і деяких метасистемних (наприклад, університету як одиниці системи вищої освіти у державі) чинників.

Аналіз останніх публікацій, дотичних до означеної проблеми (Н. П. Бусигіна, А. Н. Гусєв, Ф. Н. Барський, А. Н. Кричавець та ін. [6], О. Т. Мельникова та Д. А. Хорошилов [7], М. Вайт і Д. Епстон [13], Н. В. Чепелєва [10], П. Рікер [8], Т. Р. Сарбін [12], М. О. Аванесян [1], дозволяє зробити висновок про те, що 1) наративна психологія $є$ компромісним способом почути «голос самості» (індивідуальної особистості як его-ідентичності) в багатоголоссі ціннісних значень полікультурного дискурсу (соціального контексту); 2) наративна психологія звільняє особистість в єдності іiі різнопорядкових суб'єктних прагнень і здатностей з-під влади панівного дискурсу, делегуючи їй відповідальність за моральне самовизначення у хронотопі цілісного життєздійснення; 3) наратив як основний концепт однойменної психології $\epsilon$ розповідною, мовленнєвою формою презентації особистого досвіду в його темпоральній тяглості (минуле - теперішнє - майбутнє), який формується і проявляється в специфічному культурно-символічному середовищі; 4) наративна форма автобіографічної самопрезентації це водночас спосіб циклічно повторюваного тематичного осюжетнення (ціннісного утвердження себе як автентичної особистості та доцільного конструювання своєї життєвої траєкторії у просторі гіпотетичних можливостей і реальних шансів; 5) найпоширенішою ціннісною дилемою, представленою в наративі, виступає опозиція прагнення до прийняття i любові, афіліативна мотивація поведінки, з одного боку, і намагання контролювати хід подій через нарощування власної компетентності, що репрезентує прагнення до влади i самоствердження в референтному колі осіб, з другого боку; 6) наратив конструюється суб'єктом як автором власного життя й інсайдером у царині унікального життєвого досвіду та репрезентанта особистісно значущих прагнень і цілей; водночас наратив як породження конкретної особи має і конкретного адресата, це - сповідь перед лицем значущого Іншого (Слухача). I тільки завдяки цьому капітальному факту автор наративу «збирає себе» iз фрагментів життєвих вражень, критичної оцінки колишніх вчинків, рефлексії над пережитими подіями заради реалізації свого права на гідний (особистісно бажаний i нормативно прийнятний) проект власного життя; 7) діалогічна інтенція наративу потребує спершу достовірного опису суб'єктивної реальності Автора у спосіб феноменологічного вчування занурення у світ інтимних переживань і метафоричних кодів несвідомого, згодом дискурсивного впорядкування через поміщення опису в контекст реальних міжособистісних стосунків (інтерпретація - це з'ясування особистісного сенсу ключових моментів автобіографії для самого себе), нарешті - тлумачення (для Іншого, тобто Слухача) власної версії прожитого і пережитого, що забезпечується феноменологічним відцентруванням - розототожненням 3 «опрацьованою» (відрефлексованою) Самістю 3 метою конструювання більш адекватних альтернативних історій для видозміненого контексту (життєвих обставин) і узгодженою 3 ним Я-концепцією.

У літературі, присвяченій застосуванню теоретичних положень наративної психології в різних царинах суспільної практики, насамперед психотерапевтичної, можна знайти схожі алгоритми їх реалізації. Наприклад, Д. Фрідман і Д. Комбс пропонують такий формат практики для позитивного розвитку історій: 1) починайте з унікального епізоду. Навіть коли люди не згадують про позитивний аспект своїх переживань, запитуйте про події, що їх викликали; 2) переконайтеся в тому, що унікальний епізод представляє бажаний для людини напрям 
розвитку; 3) позначте історію на ландшафті дій, тобто встановіть, що було зроблено для того, щоб бажана подія відбулася; 4) позначте історію на ландшафті свідомості, тобто визначте, як учинок людини ii характеризує; 5) задавайте питання, що пов'язують минулий епізод i позитивний досвід його переживання з теперішнім життям людини; 6) задавайте питання, які поширюють оптимістичну історію на майбутнє, актуалізуючи суб'єктний потенціал людини на досягнення бажаних для неї цілей [9].

М. Л. Кросслі з посиланням на Д. МакАдамса [11] пропонує такий алгоритм опрацювання автобіографічного наративу (інтерв'ю), який може застосовуватися не лише в рамках психотерапії, а й поза нею як засіб самодопомоги людині у критичних ситуаціях: 1) кількаразове читання тексту записаного інтерв'ю; 2) ідентифікація важливих концептів. При цьому слід звертати увагу на тон оповіді, використовувані образи і метафори, провідні теми; 3) об'єднання матеріалу в послідовну історію; складання звіту про дослідження. У структуру ж самого інтерв'ю повинні входити питання про ключові події з дитинства, юності, зрілості тощо, запитання про значущих людей, про мрії та плани на майбутнє, перелік найбільших стресів і проблем, з'ясування базових переконань і цінностей. Відповіді на ці питання становлять вихідний емпіричний матеріал для усвідомлення й переосмислення автобіографічного наративу респондента інтерв'юером і самим респондентом [4].

Багато корисних рекомендацій, що випливають із синтезу наративної психології та конфліктології, можна почерпнути зі змістовного науково-методичного посібника П. Келлета [5], адресованого фахівцям у галузі медіації конфліктів, проведення перемовин тощо. Йдеться про налагодження конфліктного діалогу (найімовірніше добре підготовленим організаційним психологом) шляхом запровадження конструктивних способів управління конфліктом та його розв'язання.

У завдання цієї статті не входить переказ чи систематизація згаданих методичних рекомендацій, оскільки вони стосуються зарубіжного досвіду і враховують особливості менталітету й організаційної та політичної культури західних суспільств, що розвиваються в умовах тривалої демократії, верховенства права, гуманістичного скерування соціальної політики. Цим досягається баланс інтересів різних груп населення, щораз краще забезпечується гендерна рівність, розвиваються перспективні форми підприємництва на грунті економічної свободи, толеруються різні типи сім’ї та шлюбу і т. д. Україна поки що не досягла відповідних цивілізаційних стандартів, зокрема і в налагодженні результативної роботи новітніх державних інститутів 3 протидії корупції, лібералізації виборчого законодавства й обмеження впливу олігархату на державні справи, підвищення ролі органів місцевого самоврядування і зростання рівня правової свідомості й особистої моральної відповідальності громадян тощо. Відтак гостро затребуваною $\epsilon$ не стільки популяризація зарубіжних психотерапевтичних підходів 3 їх поверховою адаптацією до вітчизняного соціокультурного контексту, як реальні приклади застосування в даному випадку наративної парадигми до розв'язання актуальних завдань психологічної практики, зокрема в царині реагування на конфліктні ситуації, що виникають в організаціях.

Виклад основного матеріалу. Як відомо, у суспільствах перехідного типу, як-от в У країні, в умовах трансформації системи освіти, перегляду якісно-кількісних критеріїв оцінки ефективності науково-педагогічної діяльності працівників вищої школи, зменшення контингенту студентів практично у кожному ВНЗ внаслідок демографічної кризи та збільшення доступності освіти за рубежем посилюється конкуренція на ринку праці, яка набуває рис виразного світоглядно-ідеологічного, морально-етичного протистояння між претендентами на вакантні робочі місця, кількість яких у зазначених умовах неухильно зменшується, тоді як вимоги до рекрутантів постійно зростають. Ситуація ускладнюється тим, що такі обставини каталізують появу складних заміщених конфліктів, на перший погляд, суто ділового змісту. «Заміщений конфлікт - це результат перенесення суперечностей, які генеруються однією (наприклад, соціокультурною, гендерною, статусно-рольовою, політико-ідеологічною та ін.) 
цариною буття людини, в іншу (інтимно-особистісну, сімейну, професійну, освітньо-виховну та ін.). Заміщення, як правило, відбувається непомітно для учасника потенційного конфлікту, оскільки переноситься «серцевина» проблеми - глибинний (часто неусвідомлюваний) сенс суперечності, який виражає відмінність ціннісних устремлінь різних людей та спільнот, до яких ті себе відносять, або через залучення в які відбулася мимовільна, тобто, позасвідома ідентифікація» [3, с. 41]. Таким чином симптоматика конфлікту приростає додатковими сенсами, часто приватного характеру, які, тим не менш, можна розглянути через аксіопсихологічну оптику принципу інтегральної суб'єктності [2].

Проте перш ніж розгорнути аргументацію на користь аксіопсихологічного формату реагування на конфліктну ситуацію, пропоную зразок письмового звернення завідувача кафедри до своїх колег на піку загострення різних ліній протистоянь, коли ентропійні тенденції в організації досягли свого апогею. Вважаю, що часова дистанція (близько двох років), що відділяє зазначений період від теперішнього часу, є достатньою, аби створити безпечний простір для встановлення раціонального балансу загальної користі та персональної шкоди від публікації цього артефакту для авторки та осіб, довільно позначених буквами алфавіту в послідовності їх згадування.

«Шановні колеги!

Оцим своїм офіційним зверненням починаю свого не зовсім офіційного листа. Багато часу я витратила на обдумування того, Що, ЯК і Коли я скажу Вам те, що повинна сказати. Здається, всі три пункти зійшлися у вигідній суперпозиції. Для цього є й необхідні внутрішні передумови - розум заспокоївся і здатен відокремити «зерно від полови», дух змирився з неминучим, почуття узгодилися 3 відчуттями.

Ми (кафедра) реально стоїмо на роздоріжжі: чи продовжувати взаємопоборення, яке, як відомо, добре консолідує супроти спільного «ворога» (а я не «тягну», погодьтеся, на цю роль), сформувати свій альтернативно-прогресивний молодецький клан $\mathrm{i}$ таранити рештки ретроградно-трухлявого конгломерату та, врешті, довести зверхникам свою правоту і розділити між собою заслужено здобутий у тяжкій, але надихаючій боротьбі, трофей на кшталт повних ставок для себе, вищих рангів у статусній ієрархії тощо, чи, може, здійснити внутрішню інвентаризацію «світла» і «тіні», фактів і версій, реалістичних очікувань та ілюзорних сподівань, розважливого аналізу і «праведного» гніву. Я звертаюся до першої з виокремлених опозицій - раціональної сторони нашої людської природи, який, сподіваюся, допоможе здійснити нам (мені і Вам) правильний моральний вибір.

Ви, мабуть, погодитеся зі мною, що прожитий навчальний рік був найкритичнішим за всю 17 річну історію кафедри, позаяк сповнений болю, взаємних образ, непорозумінь, страхів, розчарувань, хоча прелюдія цих буремних подій була зіграна ще в минулому році, коли Ви делегували мені право запропонувати принцип розподілу навчального навантаження при явній нестачі ставок на всіх викладачів. Тоді я скористалася цим правом у той спосіб, що запропонувала тимчасово (оскільки у всіх на той час були чинні контракти) визнати пріоритетним критерій соціального захисту, а саме: чим більше часу (років) викладач суміщає роботу з отриманням пенсії, тим більший коефіцієнт особистих поступок (наприклад, планування навантаження в 0,7 чи 0,9 ставки) заради молодшого, менш досвідченого, але з більшим потенціалом професійного зростання і менш матеріально захищеного колеги. Старше покоління неохоче, та все ж із розумінням, прийняло цю пропозицію, пішло на деякі самообмеження, і лише А. вдала, що погодилася, і навіть попросила зменшити іiі 0,6 ставки (ще 0,25 ставки у неї було по лінії...), а пізніше, будучи викритою в отриманні зарплати по кафедрі за повну ставку (розповідала, що не здогадувалася про те, що отримувала більше, ніж належиться; та й узагалі завжди була проти обмеження обсягу свого навантаження ... зрештою, Ви знаєте цю історію, не буду вдаватися в деталі).

Чи була вона покарана за шахрайство (якщо називати речі своїми іменами)? Якщо це шахрайство носило ненавмисний характер, то чому замість вибачень я зустрілася з відчайдушними спробами вигородити себе і перекинути відповідальність за власний «недогляд» на мене як іiі безпосереднього начальника? Я мусила давати роз'яснення в різні інстанції, та оскільки документообіг свідчив, що з мого боку ніяких порушень не було, то й претензії до мене з боку університетських зверхників не висловлювалися. Інцидент зам'яли, що було половинчастим розв'язанням проблеми. Старше покоління 
через законодавчу неврегульованість питання щодо працюючих пенсіонерів отримало сигнал більш упевнено відстоювати свої права, нехтуючи «необов'язковими» моральними аргументами. Це актуалізувало на кафедрі конфлікт поколінь, що позначилося на стриманій підтримці мене як завідувача (з боку старших) і сподіваннями молодших як більш сучасних і перспективних, 3 іншого боку, на ефективніше відстоювання їхніх прав на «місце під сонцем». А оскільки осіб пенсійного й далеких від пенсійного віку на кафедрі майже порівну, ситуація (скритий міжпоколінний конфлікт) загрожувала перерости у жорстке протистояння колишніх педагогів і наукових керівників та колишніх студентів $\mathrm{i}$ аспірантів, що додавало ситуації (a - ?) моральної пікантності.

Та сталося дещо, що змістило фокус протистояння 3 міжгрупового на особистісно-груповий, а саме: керівництво університету через усні директиви декану, а особливо мені як завідувачеві кафедри наполегливо рекомендувало надати Б. ексклюзивне право на повне навантаження (при тому, що термін чинності її контракту сплив). Це різко контрастувало з нашими можливостями (брак ставок), правами інших (штатних) працівників й уявленнями про справедливість. Об'єктивною підставою для протекціонізму щодо Б. було те, що ії чоловік боронив незалежність України як добровільний учасник АТО (невдовзі після демобілізації він помер від інсульту). Крім того, Б. звертала увагу на своє незадовільне матеріальне становище, гірше, з ії слів, ніж у пересічного викладача. Задля більшої переконливості Б. 3'являлася в університеті у супроводі ... ветеранів АТО, які тиснули ухвалити рішення в інтересах їх підопічної. Слід віддати належне далекоглядності керівництва та його спробі попередити невдоволення членів кафедри, передавши викладання дисциплін, які раніше не були у ії розпорядженні, у виняткове «володіння» пані Б. Правда, при цьому довелося перевищити дозволену для викладання одним викладачем кількість предметів, а також звільнити молодого кандидата наук, який викладав ці дисципліни раніше на умовах строкового трудового договору. На жаль, з боку керівництва мотив уникнення неприємностей переміг мотив досягнення успіху - більшої користі для студентів ... в разі їх навчання викладачем, який апробував ці дисципліни і не був переобтяжений додатковими предметами, ніж від викладання доцентом, який починає воднораз кілька курсів, що називається, «з коліс». Шкода, що ця обставина нікого всерйоз не збентежила. У що вилився цей компроміс побачили згодом.

Більшість із нас дала добровільно-примусову згоду, дозволивши застосувати щодо себе інші (неписані) правила гри. Всі, крім В., яка навідріз відмовилася працювати менше, ніж на ставку. В юридичному сенсі вона мала рацію, в корпоративному - ні, адже це був мовчазний, хоч і діяльний щодо себе, виклик нав'язаним зверху виняткам, які запроваджуються всупереч нормативним документам, що регулюють діяльність університету. Тоді «упали» в зарплаті всі, крім неї. Задля пом'якшення невдоволення я теж пішла на добровільне самообмеження, перейшовши на 0,8 ставки, що, напевно, $\epsilon$ безпрецедентним у моєму становищі. Принаймні, мені невідомі факти, щоб ще хтось із завідувачів кафедр університету так себе покарав, проявивши солідарність 3 колективом і відчуваючи свою безсилість щось змінити. Я сподівалася, що цей мій крок буде позитивно оцінений Вами, але на підсвідомому рівні це спрацювало інакше - як маркер слабкого керівника, нездатного (через надмірну лояльність? недостатнє служіння кафедрі?..) захистити інтереси своїх працівників і протистояти феномену подвійної моралі.

Ви вирішили, що я докладаю недостатньо зусиль для того, щоб довести, що політична кон 'юнктура, спекуляція на патріотизмі не повинні позначатися на діяльності університету як незаангажованої освітньо-наукової установи. Ви вирішили, що я здалася, і тепер Ви вимушені боротися самостійно. I деякі з Вас обрали таку тактику: начальство - просити, а мене - провокувати через погано приховані насміхання, відмову від виконання моїх доручень, чіпляння за слова, що, напевно, мало розцінюватися мною як спонукання до активніших дій в інтересах кафедри, а особливо - iї молодшого первня. Погодьтеся, це не зовсім чесно: замість того, щоб зміцнювати кафедру в ії переважаючому здоровому сегменті, про наявність якого промовисто свідчило голосування за заміщення вакантної посади доцента кафедри (8 голосів - за Г. і лише 2, включаючи ії саму, - за Б.), троє з Вас виокремилося (Г., Д., Е.) i звернулося до керівництва з викриттям фактів, які дискредитують Б. як викладача і науковця. 3 фактами я згідна, з позицією - ні. Чи була адекватна реакція на Вашу заяву? Ні. Чи лише тому, що писали їі Ви? Hi. А коли б нас восьмеро підписалося, це спрацювало б? Припускаю, що теж ні!

До чого ж я веду, спитаєте Ви? Якщо й локальна (на рівні кафедри) солідарність нічого не вирішує, то де вихід? 
Своєю чергою я запитую: «Що дає Вам зміщення конфлікту з проблем, закладених на метарівні?» Наприклад, оцінка «коефіцієнта корисної дії» працівника за його вміння бути «корисним ідіотом» - нашіптувати вищому керівництву, доносити, підлещуватися, підкупати тощо. Чи випадково А. знову була «спіймана» на перенесенні термінів завершення свого контракту з лютого $20 \ldots$ року на грудень $20 \ldots$ року? Хто має можливість вносити такі корективи? Не я і не Ви. Або: незадоволення соціальних гарантій для сімей колишніх учасників АТО на державному рівні перекладає невластиву функцію на керівництво університету, якому теж варто поспівчувати, бо що вища точка домінування, тим відчутніша сила падіння! I не лише для його очільників, а й для нас самих! Якщо, звісно, ми здатні до децентрації та об’єктивувальної рефлексії. Чому Б. скористалася цією нормативно-правовою розбалансованістю, спрямувавши свій гнів через цю ситуацію на колег, які раптово стали ії ворогами, i переклавши відповідальність за непоправну особисту втрату (смерть чоловіка) не на українську державу (що абстрактно), а фактично на своїх співробітників - це, видно, пояснюється iї відданістю сім'ї, «патріотом» якої вона завжди була. Що від того порушуються принципи демократичного самоврядування, професійної конкурентності (студенти, як показує соціологічне опитування, низько оцінюють іï науково-педагогічні здібності), іiі не сильно хвилює. Адже раз добившись перемоги на повторних виборах (після того, як Г. зняла свою кандидатуру з голосування) на вченій раді університету, тоді як попередні (на кафедрі та тій же вченій раді) голосування дали несприятливі для неї результати, вона лиш закріпила тактику шантажу і маніпуляцій.

Ви спитаєте, для чого я пропоную Вам це нудне чтиво, адже все і без нього відомо? Куди ж вона хилить? Чи здатна запропонувати шлях вирішення проблеми, який не був би шляхом помсти або шляхом віртуозних багатоходових маніпуляцій? Заінтригувала? Важко повірити, що я здатна на друге, адже моя прямота і відвертість (я схильна думати, що це чесність) - широко відомі. Помсти? Ми ж не прайд гомінідів, особини якого топчуть знесиленого вожака, толеруючи груповий егоїзм в особі сильного і хижого! А, може, Вам ближча метафора про українця, який піде на те, щоб дати виколоти собі око лишень заради того, щоб сусідові викололи обидва?

Даруйте мені ці гіперболізовані аналогії. Насправді перш ніж братися за цей лист, я подумки перегорнула сторінки нашої спільної історії. І так мені легко, світло і тепло стало на душі! Я наче знову побачила, як ми з $Є$. та ін. не могли розійтися після 30 червня, бо ще два тижні утрясали своє без-розмір-не кафедральне навантаження, шукаючи сумісників, а я раділа, що Ви можете взяти стільки, скільки можуть дати, тобто, півтори ставки впродовж багатьох років, поки університет ще міг розвиватися екстенсивним шляхом. Я згадала, як ми починали з Г. з курсової роботи на тему трансактного аналізу, а потім зайнялися автентичністю (вона не хотіла зв'язуватися з віктимністю - темою, що випливала 3 ТА, позаяк побоювалася негативного самопрограмування), потім я придумала «зірочку» - просторову метафору, що впорядковувала поняттєвий апарат дослідження. Також вона вперше 3 моїх аспірантів застосувала кластерний аналіз (у неї хист до математики!), скориставшись статтею В.О. Климчука, яку я ій порекомендувала. Згадалося, як ми з В. ризикнули представити цілком герменевтичне дослідження 3 мінімальною кількістю досліджуваних (виступили, так би мовити, супроти домінуючого тренду i, на щастя, успішно!); тепер вона - чудовий феноменолог. Ми їздили з нею в Хорватію, Італію, вражень - на все життя! Е. зі студентських років вражав мене своїм ентузіазмом і залюбленістю в науку, а потім ще й добродушним гумором. І. - мовчун, дорожить словами, але він - справжній, без фасаду. В його мовчання і скупі слова треба вслухатися, вчутися, і тоді вони багато розкажуть. Ї. - справжній океан, а ще його дивовижної краси перлинка. До іiі ерудиції, розуму і шляхетності мало хто може дорівнятися. Д. був найлояльнішим, найнадійнішим і багато в чому най-най. Але він трохи схибив. Ну що ж, буває.

Ви здатні на самопожертву. Троє моїх молодих колег і критиків, тим не менш, здали кров для моєї мами, коли та лікувалася від тяжкої недуги. Завжди буду їм вдячна. Ніколи не забуду похорони наших рідних, коли ми трималися разом.

Всі ці спогади і враження гріють душу і зміцнюють у переконанні, що все було не марно. Ми зростали разом, як єдиний організм. Але, зростаючи, організм диференціюється на тканини, органи, він ускладнюється, розшаровується. Взаємодіючи 3 більшими системами, сам породжує 3 себе менші системи. Ми, природно, вже не такі єдині в помислах, як раніше. Кажучи це, я усвідомлюю, що схильна трохи переоцінювати позитив на тлі проблемного поточного моменту. Та все ж спільне позитивне минуле - це те життєдайне джерело, 3 якого ще довго можна черпати сили для знаходження нових сенсів. 
Наші конфліктні взаємини - це хвороба росту, внаслідок чого старе повинно поступитися місцем молодому. Я маю на увазі не старість як віковий період, а як організаиійний застій, пов'язаний 3 інертністю думки, вичерпаністю ресурсів і (не дай, Боже!) 3 духовною деградацією. Моє падіння до 0,8 ставки - це не просто самопожертва, це символічний акт капітуляції перед несправедливістю, це акт самопокарання і самоприниження, який не призвів і не міг призвести до розв'язання проблеми, а лише продовжив стагнацію.

Я також розумію, що розлад наших з Вами стосунків - це заміщений, тобто, багато в чому надуманий конфлікт. Чи були б стосунки такими, якими вони стали, якби не існувало «заповідних зон» для різного роду недоторканих осіб, якби університет як освітньо-наукова установа тільки таким i залишався, а не був «розплідником» різного роду бездарних сексотів, єдиною доблестю яких $\epsilon$ запопадливість перед «власть імущими»? Якби рейтинг наукової спроможності викладача вимірювався насамперед самостійністю продукованих текстів, перевірених програмами пеленгування плагіату, а не місцем розміщення статей (фахове видання чи збірник матеріалів конференції); якби участь в акредитаційній комісії іншого ВН3 цінувалася значно менше, ніж участь у підготовці ліцензійної справи власного ВНЗ і т. д. Відтак хочу вірити у Вашу моральну силу і мужність, аби крок за кроком виборювати не власні «ставки», а право на гідність, на утвердження справедливості. Без компромісів і поступок тут не обійтися, бо хто без гріха? Перш ніж вимагати від когось, варто почати із себе. Пам'ятайте про це! Я старалася слідувати цьому правилу все своє життя. Завжди вважала, що особистий приклад - найкращий засіб впливу. Я була і залишаюся доброї думки про людей та їхню здатність наслідувати добре. На жаль, наслідується не тільки добре, ми це знаємо.

Міркуючи про долю кафедри, я думаю про неї, як матір про своє дитя. Дитина виросла, їй уже 17 років, через рік настане повна юридична відповідальність. Чи хочу я, щоб мої символічні діти (колеги) пішли в прийми на інші кафедри, навіть якщо їх очолюють мудрі завідувачі? $\mathrm{Hi}$, не хочу, бо прийми $\epsilon$ прийми. Ви будете радше гостями (не факт, що бажаними) на чужому весіллі. А гостю слід поводитися чемно, інакше випровадять!

Лише в своїй хаті можна здобути «і правду, і волю». Закликаю Вас обрати зі своїх лав людину, яка найкраще впорається з обов'язками завідувача і не дозволить поводитися з собою, як з «технічною прокладкою» між вищим і нижчим рангами владно-підвладної вертикалі. Гадаю, ми швидко знайдемо цю людину. Ми іiї знаємо, і я погоджуся з Вашим рішенням. Понад усе я заслужила час на своє фізичне й психологічне відновлення, розототожнення 3 Вашими негативними проекціями $\mathrm{i}$ власними непродуктивними контрзаходами. Мені є куди спрямувати свої сили, є задля чого i кого жити $\mathrm{i}$ працювати. Отож я пишу заяву про звільнення від обов'язків завідувача кафедри ..... за власним бажанням.

3 повагою і довірою ... »

Публікація вищенаведеного автобіографічного наративу звільняє мене від необхідності його докладного аксіопсихологічного транскрибування й рефлексивного опрацювання, тим паче що відповіді на ключові зауваги щодо опису конфліктної ситуації, іï чинників, обгрунтування ціннісної позиції авторки, бачення нею шляхів продуктивного виходу зі складного плетива професійних інтересів, особистих амбіцій та ін. у тексті наведено. Допіру йдеться про артикуляцію критеріїв валідності (якості) автобіографічного наративу, рекомендованого до застосування в організаційній царині аксіопсихології:

1) достовірне (відкрите, щире і чесне) змалювання чуттєвого фону авторського переживання значущих подій - рівень тілесної самості, організмічного чуття особи як відносного суб'єкта життєдіяльності;

2) об'єктивна (фактологічна) фіксація нормативно-правового і функціонально-рольового статусу дійових осіб автобіографічного наративу з посиланням на їхні реальні вчинки - рівень власне суб'єкта (моносуб'єкта) як агента умовно індивідуальної професійної діяльності (тобто такої, що розглядається з позиції персонального внеску - користі працівника для організації;

3) презентація власної морально-етичної позиції стосовно фактів (подій, вчинків персонажів, ситуацій), викладених у наративі, - рівень полісуб'єкта як особистості, залученої до спільної діяльності організації з різними персональними мотивами, цінностями, цілями, інтересами; 
4) поміщення автобіографічного наративу в ширший соціокультурний контекст з метою визначення вектора дрейфу приватної історії в дискурсі державотворення, публічної політики, тенденцій зміни національної ментальності тощо - рівень метасуб'єкта як творчої індивідуальності, вписаної у спосіб і стиль життя великої спільноти;

5) чистосердечна сповідь, критичне самооцінювання, розкаювання за помилки в потоці автентичного духовного тяжіння до ідеалу досконалого діяння, втіленого у житті-подвигу Боголюдини - рівень абсолютного суб'єкта, універсальної іпостасі життєздійснення особи.

Висновки. Ієрархічна конфігурація наведених критеріїв валідності автобіографічного наративу виражає різні функціонально-процесуальні акценти його аксіологічного змісту: 1) тілесне переживання-відчування; 2) сприймання як ідентифікацію ресурсів нормативноадаптивної поведінки; 3) моральне самовизначення в контексті сумісно розподіленої діяльності; 4) ціннісне самоствердження в суспільно значущій культуротворчості; 5) актуалізацію в процесі життєздійснення особистості універсальних суб'єктних здатностей через сповідування абсолютних духовних цінностей, втілених у гуманістичному світогляді, - синергійний результат інтуїтивного вчування й рефлексивного зусилля автора наративу.

1. Аванесян, М. О. Альтернативная автобиографическая история как составляющая возможного «я». Психологические исследования. 2018. Т. 11. № 61. Взято из http://psystudy.ru/index.php/num/2018v11n61/ 1619avanesyan61.html.

2. Карпенко, 3. С. (2018). Аксіологічна психологія особистості: монографія. Івано-Франківськ: ДВНЗ «Прикарпатський національний університет імені Василя Стефаника».

3. Карпенко, 3. (2017). Керівник як медіатор у розв'язанні заміщених службових конфліктів. Бойчук Л. В. (Ред.), Професійна освіта управлінських кадрів: проблеми, дослідження, досвід. (с. 41-44). Івано-Франківськ: ІФОЦППК.

4. Кроссли, М. Л. (2013). Нарративная психология. Самость, психологическая травма и конструирование смысслов. Харьков: «Гуманитарный Центр.

5. Келлетт, П. (2010). Конфликтный диалог: работа с пластами значений для продуктивных взаимоотнотений. Харьков: «Гуманитарный Центр».

6. Мельникова, О. Т, Кричевец, А. Н., Гусев, А. Н., Хорошилов, Д. А., Барский, Ф. И. \& Бусыгина, Н. П. (2014). Критерии оценки качественных исследований. Национальный психологический журнал, 2 (14), 49-51.

7. Мельникова, О. Т. \& Хорошилов, Д. А. (2015). Стратегии валидизации качественных исследований в психологии. Психологические исследования,8 (44). Взято из http://psystudy.ru/index.php/num/ 2015v8n44/1207melnikova44.html.

8. Рикер, П. (1995). Конфликт интерпретаций: Очерки о герменевтике. Москва: Медиум.

9. Фридман, Дж. \& Комбс, Дж. (2001). Конструирование иных реальностей: Истории и рассказы как терапия. Москва: Независимая фирма «Класс».

10. Чепелєва, Н. В. (Ред.) (2007). Наративні психотехнології. Київ: Главник.

11. McAdams, D. (1993). The Stories we live be: Personal Myths and the Making of the Self . New York: Morrow.

12. Sarbin, T. R. (Ed.) (1986). Narrative Psychology: The Storied Nature of Human Condukt. New York: Praeger.

13. White, M. \& Epston, D. Narrative Means Therapeutic Ends. New York: Norton.

\section{REFERENCES}

1. Avanesyan, M. O. Al'ternativnaya avtobyograficheskaya istoriya kak sostavlyayushchaya vozmozhnoho «ya» [Alternative autobiographical history as a component of a possible «me»]. Psykholohycheskye yssledovanyia [Psychological research.]. 2018. T. 11. № 61. Retrieved from http://psystudy.ru/index.php/num/2018v11n61/1619avanesyan61.html. (rus).

2. Karpenko, Z. S. (2018). Aksiolohichna psykholohiia osobystosti: monohrafiia [Axiological psychology of personality: monograph]. Ivano-Frankivsk: DVNZ «Prykarpatskyi natsionalnyi universytet imeni Vasylia Stefanyka». (ukr).

3. Karpenko, Z. (2017). Kerivnyk yak mediator u rozviazanni zamishchenykh sluzhbovykh konfliktiv. Boichuk L. V. (Red.), Profesiina osvita upravlinskykh kadriv: problemy, doslidzhennia, dosvid. (p. 41-44). Ivano-Frankivsk: IFOTsPPK. (ukr).

4. Krossly, M. L. (2013). Narrativnaya psikhologiya. Samost', psikholohycheskaya travma i konstruirovaniye smyslov [Narrative psychology. Self, psychological trauma and construction of meanings]. Khar'kov: «Gumanitarnyy Tsentr. (rus).

5. Kellett, P. (2010). Konflyktnyy dialog: rabota s plastamy znacheniy dlya produktivnykh vzaimootnosheniy [Conflict dialogue: working with layers of values for productive relationships]. Khar'kov: «Gumanitarnyy Tsentr». (rus). 
6. Mel'nikova, O. T, Krichevets, A. N., Gusev, A. N., Khoroshilov, D. A., Barskiy, F. Y. \& Busygina, N. P. (2014). Kriterii otsenki kachestvennykh issledovaniy [Criteria for evaluating qualitative research]. Natsional'nyy psikholohycheskiy zhurnal [National Journal of Psychology], 2(14), 49-51. (rus).

7. Mel'nikova, O. T. \& Khoroshilov, D. A. (2015). Strategii validizatsii kachestvennykh issledovaniy v psikhologii [Strategies for validating qualitative research in psychology]. Psikhologicheskiye issledovaniya [Psychological research], 8 (44). Retrieved from http://psystudy.ru/index.php/num/2015v8n44/1207-melnikova44.html. (rus).

8. Ryker, P. (1995). Konflikt interpretatsiy: Ocherki o germenevtike [Conflict of Interpretation: Essays on Hermeneutics]. Moskva: Medyum. (rus).

9. Fridman, Dzh. \& Kombs, Dzh. (2001). Konstruirovaniye inykh real'nostey: Istorii i rasskazy kak terapiya [Constructing other realities: Stories and stories as therapy]. Moskva: Nezavisimaya firma «Klass». (rus).

10. Chepelieva, N. V. (Red.) (2007). Naratyvni psykhotekhnolohii [Narrative psychotechnology]. Kyiv: Hlavnyk. (ukr).

11. McAdams, D. (1993). The Stories we live be: Personal Myths and the Making of the Self. New York: Morrow. 12. Sarbin, T. R. (Ed.) (1986). Narrative Psychology: The Storied Nature of Human Condukt. New York: Praeger. 13. White, M. \& Epston, D. Narrative Means Therapeutic Ends. New York: Norton.

\section{Zinoviia Karpenko \\ FROM THE EXPERIENCE OF AUTOBIOGRAPHICAL NARRATIVE APPLICATION IN ORGANIZATIONAL PSYCHOLOGY: AXIOLOGICAL OPTICS}

From the standpoint of post-non-classical rationality and post-postmodernist searches for a holistic approach to the interpretation of person's psychology as an integral subject of life realization the experience of using autobiographical narrative in the context of managing and solving complex (often substituted) conflicts in the organizational environment of higher education is highlighted. It is stated that such a narrative is constructed by the subject as the author of his own life and the insider in the field of unique life experience as well as the representative of personally meaningful desires and goals. The dialogical intention of the autobiographical narrative requires an authentic description of the subjective reality of the Author in the way of primary phenomenological feel - immersion into the world of intimate experiences and metaphorical codes of the unconscious, and thus discursive ordering of the described events and their assessments through the consideration of individual history in the context of real interpersonal relationships (interpretation for himself and explanation of his own version of experienced to Another).

The axiopsychological criteria of the validity of autobiographical narrative as a means of initiation of productive dialogical communication by the leader for strengthening the healthy tendencies of the development of educational and scientific organizations in the context of eurointegrational processes, harmonization of personal trajectories of professional and career growth within the initial collective; strengthening of personal responsibility for the results of moral self-determination in critical situations; the formation of tolerance to uncertainty and readiness to adopt non-standard decisions as an opportunity to support promising developmental lines by having separated them from rigid, outdated practices of educational management are argued.

Keywords: autobiographical narrative, narrative psychology, axiological psychology, organizational psychology, person as an integral subject, conflict, higher school. 